\title{
Physiological and Sanitary Quality in Cowpea Seeds Produced in Rio Grande Do Norte, Brazil
}

\author{
Ronimeire T. da Silva ${ }^{1}$, Maria de F. Q. Lopes ${ }^{1}$, Francisco H. A. de Andrade ${ }^{2}$, Riselane de L. A. Bruno ${ }^{1}$, \\ Otília R. de Fárias ${ }^{1}$, Toshik I. da Silva ${ }^{3} \&$ Nelto A. de Souza ${ }^{4}$ \\ ${ }^{1}$ Department of Plant Science and Environmental Sciences, Federal University of Paraíba, Areia, Paraíba, Brazil \\ ${ }^{2}$ Department of Biology, Federal University of Lavras, Lavras, Minas Gerais, Brazil \\ ${ }^{3}$ Department of Plant Science, Federal University of Viçosa, Viçosa, Minas Gerais, Brazil \\ ${ }^{4}$ Department of Plant Science, Federal University of Santa Maria, Santa Maria, Rio Grande do Sul, Brazil \\ Correspondence: Ronimeire T. da Silva, Department Plant Science and Environmental Sciences, Federal \\ University of Paraíba, Areia, Paraíba, Brazil. E-mail: ronimeiretorres@hotmail.com
}

Received: November 6, 2018

Accepted: December 17, 2018

Online Published: February 15, 2019

doi:10.5539/jas.v11n3p581

URL: https://doi.org/10.5539/jas.v11n3p581

\begin{abstract}
The importance of cowpea (Vigna unguiculata (L.) Walp.) to the Northeast region of Brazil is undeniable, it is a major crop in local family agriculture. As a result, the research aimed to evaluate the physiological and sanitary quality of local varieties of cowpea coming from the state of Rio Grande do Norte. The experiment was carried out at the Seed Pathology and Seed Analysis Laboratory, in Federal University of Paraíba, Campus II, Areia, Paraiba, Brazil. Six cowpea varieties (Baeta, Coruja, Sempre Verde, Epace 10, Feijão da Bahia and Pingo de Ouro) from rural Area of the municipality of Apodi, Rio Grande do Norte, Brazil.were evaluated Seed physiological quality was evaluated by determining the first germination count (FGC), germination percentage (G\%), seedling length (SL) and electrical conductivity (EC). The sanitary quality of the seeds was evaluated by the method of incubation in filter paper (blotter test). The experimental design was completely randomized, with 4 replicates. The Pingo de Ouro, Sempre Verde and Coruja varieties had germination percentages greater than the minimum standards required for commercialization, while the lower germination percentage and vigor of the Feijão da Bahia, Epace 10 and Baeta varieties may be associated with the presence of Aspergillus sp. and Penicillium sp.
\end{abstract}

Keywords: germination, fungal incidence, Creole seeds, Vigna unguiculata L.

\section{Introduction}

The cowpea (Vigna unguiculata (L.) Walp.), also known as string bean or Macassar bean is a legume predominantly cultivated by family farmers. It is considered as the staple food of the population, receiving great attention in the social and economic area because the low production cost and high nutritional value (Calvet et al., 2013; Fernandes et al., 2015). It develops satisfactorily in soils of low fertility (Silva, 2007), and considered moderately tolerant to salinity (Fageria et al., 2010). In Brazil, production in the year 2016/2017 was 713.3 thousand tons, and the production was mainly concentrated in the Northeast region. Planting starts from the first rainfall records, since the crop is large a fact that can also be attributed to its characteristics of water stress tolerance (CONAB, 2017).

The use of Creole seeds in agriculture is of extreme importance because of their high genetic diversity, which is fundamental for breeding programs, making it necessary to know the physiological potential of these varieties (Tsutsumi et al., 2015). In addition, it presents several advantages such as resistance to pests and diseases and good adaptation to local conditions as a result of the several cultivation generations carried out by the farmers, since these genotypes are influenced by environmental factors and consequently are endowed with greater greater genetic diveristy (Coelho et al., 2010).

The quality of the seeds used for planting is essential to guarantee crop establishment and good production (Tropaldi et al., 2010), ensuring uniformity in the plant stand and absence of diseases that are caused via seeds and consequently it will constitute vigorous plants (Souza et al., 2013). Usually, certain parameters are used to evaluate seed quality, these may include the seed's genetic, physical, physiological and sanitary nature (Marcos 
Filho, 2015). From these parameters, the seed sanitary quality is highlighted, since it constitutes an efficient means of disseminating pathogens from a contaminated lot, the disease can be introduced into new areas, causing seedling death (Henning, 2005). The pathogens may be present on the surface, inside or mixed in the seed itself, presenting in various forms including spores to resistance structures (Santos et al., 2011). As a result, the research objective was to evaluate the physiological and sanitary quality of local cowpea varieties (Vigna unguiculata (L.) coming from the State of Rio Grande do Norte, Brazil.

\section{Material and Methods}

The work was developed at the Laboratories of Seed Pathology and Seed Analysis, in Federal University of Paraíba (UFPB), Campus II Areia, Paraíba, Brazil. Seeds of six varieties of cowpea $\left(\mathrm{V}_{1}\right.$ : Baeta, $\mathrm{V}_{2}$ : Coruja, $\mathrm{V}_{3}$ : Sempre Verde, $\mathrm{V}_{4}$ : Epace 10, $\mathrm{V}_{5}$ : Feijão da Bahia, and $\mathrm{V}_{6}$ : Pingo de Ouro), from rural farmers of Córrego Site, Zona Rural of the Municipality of Apodi, Rio Grande do Norte, Brazil. After the harvest until conducting the experiment, the seeds were stored in pet bottles (polyethylene terephthalate) for a year, the same time equal to what farmers use, until new planting.

At the beginning, the seed water content was determined by the oven method at $105 \pm 3{ }^{\circ} \mathrm{C}$ for 24 hours (MAPA, 2009). Subsequently, physiological and sanitary quality tests were performed. For the evaluation of the physiological quality, the seeds were submitted to the germination and vigor tests according to the methodology described in the Rules for Seed Analysis (MAPA, 2009). The germination test was carried out using four replicates of 50 seeds for each variety, distributed under rolls of germitest $^{\circledR}$ type paper moistened with distilled water 2.5 times the weight of the dry paper, placed at a temperature of $25 \pm 0.5{ }^{\circ} \mathrm{C}$ and 12 -hour photoperiod. The percentage of germinated seeds (normal seedlings) was recorded on the fifth and ninth day after the test initiation (MAPA, 2009).

The vigor of the seeds was evaluated through the first germination count (FGC), performed on the fifth day after the germination test was installed and the result expressed as a percentage of normal seedlings. In addition it was classified into very high vigor: greater than $80 \%$; high vigor: between 70 to $79 \%$; average vigor: between 50 to 69\%; low vigor: between 30 and 49\%; and very low vigor: less than $29 \%$ (Vieira \& Carvalho, 1994).

At the end of the germination test, seedling evaluation was carried out, measuring the length using a ruler graduated in centimeter of 20 random seedlings. The mean seedling length value was obtained by the arithmetic mean of the number of seedlings for each replicate, and the result expressed in $\mathrm{cm}$.

For the electrical conductivity test (EC), four replicates of 50 seeds previously weighed and submitted to a plastic container containing $75 \mathrm{~mL}$ of distilled water and maintained in a germinator at $25^{\circ} \mathrm{C}$ for 24 hours were used. After this period, the electrical conductivity was measured in the impregnation solution using a conductivi meter (Mars, model MB-11P), whose results were expressed in $\mu \mathrm{S} \mathrm{cm}^{-1} \mathrm{~g}^{-1}$.

The experimental design was completely randomized, with four replicates. Data were submitted to analysis of variance by the $\mathrm{F}$ test. The averages were compared by the Tukey test, at $5 \%$ probability using the Sisvar software (Ferreira, 2014).

The sanitary quality of the seeds was evaluated by the method of incubation on filter paper (Blotter test), using 200 seeds (ten replicates of 20 seeds) for each variety. The seeds were distributed in Petri dishes containing two sheets of filter paper $\left(80 \mathrm{~g} \mathrm{~m}^{1}\right)$ previously sterilized and moistened with sterile distilled water (SDW) 2.5 times the weight of the dry paper. The plates were incubated at $20 \pm 2{ }^{\circ} \mathrm{C}$ and photoperiod for 12 hours. The quantitative and qualitative evaluations of the fungi associated with the seeds were carried out after seven days of incubation, and the seeds were examined individually under a stereoscopic microscope.

\section{Results and Discussion}

The water content of the seeds ranged from $10.52 \%$ to $12.15 \%$ in the Pingo de Ouro and Feijão da Bahia varieties, respectively (Table 1). These values are higher than those observed by Talamini et al. (2010) in which the physiological and sanitary quality of bean seeds (Phaseolus vulgaris L.) from family farmers in Sergipe, Brazil, obtained water content ranging from $8.6 \%$ to $10.70 \%$. This difference can be related to the drying practice performed by the producers after the harvest, as well as by the climatic conditions of each region. However, this value is within the moisture pattern for bean seeds. According to Bragantini (2005), when the humidity of bean seeds is between $11 \%$ and $13 \%$, the respiratory process remains low, prolonging the maintenance of seed quality. 
Table 1. Moisture, vigor, germination, seedling length, and electrical conductivity in cowpea (Vigna unguiculata L.) varieties, produced in the state of Rio Grande do Norte

\begin{tabular}{llllll}
\hline Varieties & Moisture content & Vigor & Germination & CP & EC \\
\hline & $---10-1.91$ & $62 \mathrm{abc}$ & $67 \mathrm{~b}$ & $4.5 \mathrm{abc}$ & $143.2 \mathrm{~d}$ \\
Baeta & 11.94 & $71 \mathrm{ab}$ & $89 \mathrm{a}$ & $4.8 \mathrm{a}$ & $132.7 \mathrm{c}$ \\
Coruja & 11.58 & $86 \mathrm{a}$ & $96 \mathrm{a}$ & $4.01 \mathrm{abc}$ & $106.7 \mathrm{~b}$ \\
Sempre Verde & 11.88 & $32 \mathrm{~d}$ & $67 \mathrm{~b}$ & $3.99 \mathrm{bc}$ & $145.5 \mathrm{~d}$ \\
Epace 10 & 12.15 & $40 \mathrm{c}$ & $54 \mathrm{~b}$ & $3.87 \mathrm{c}$ & $140.8 \mathrm{~d}$ \\
Feijão da Bahia & 10.52 & $92 \mathrm{a}$ & $97 \mathrm{a}$ & $4.7 \mathrm{ab}$ & $65.33 \mathrm{a}$ \\
Pingo de Ouro & &
\end{tabular}

Note. Means followed by the same letter in the column do not differ statistically by the Tukey test, at $5 \%$ probability.

The Pingo de Ouro and Sempre Verde varieties showed very high vigor $92 \%$ and $86 \%$ of normal seedlings at the first germination count, respectively. The Coruja variety has high vigor presenting $71 \%$ of normal seedlings. Mean vigor with $62 \%$ of normal seedlings is the Baeta variety. The varieties that presented low vigor were Feijão da Bahia and Epace 10 with $40 \%$ and $32 \%$ vigor, respectively (Table 1). These results differ from those observed by Silva et al. (2008), which evaluated the physiological and health quality of common bean (P. vulgaris) seeds from the State of Goiás, Brazil, observed low values of vigor for the varieties Aporé, Roxo 90, Corrente, Jalo Precoce and BRS Talisman, 21.09\%, 7.43\%, 9.93\%, 17.23\% and 33.23\%, respectively. This difference among varieties may be associated with several factors. According to Carvalho \& Nakagawa (2012), the physiological quality of the seeds can be influenced by the size of the seed, storage forms and conditions, sanitary conditions and physical and genetic constitution. It should be considered that the greater the seed vigor, the better the establishment of the field crop, increasing the stand uniformity and consequently, allowing a greater productivity (Moraes, 2006).

The germination values of the evaluated varieties ranged from (54\% to $97 \%)$. The varieties with the greatest germination percentages were Pingo de Ouro, Sempre Verde and Coruja (97\%, 96\% and 89\%), respectively (Table 1). These varieties are within the twinning standard proposed by the Brazilian Seed and Seed Association, which is 80\% (ABSM, 2013). Coelho et al. (2010) obseved that Phaseolus vulgaris L. seed from the municipality of Lajes, State of Santa Catarina had germination values above $80 \%$, thus showing the physiological potential of Creole seeds.

Feijão da Bahia (54\%), Baeta and Epace 10 (67\%) presented germination of less than 70\% (Table 1). These results differ from those found by Gomes et al. (2008) who studied the physiological quality and the incidence of fungi in cowpea seeds produced in the State of Ceará. The germination for Sempre Verde cultivar was 70.33\% and other cultivars (Epace 10, Canapu, Costela de vaca, Lizão 1, Lizão 2, Corujinha, Parambú, Galanjão, Pingo de 1, Pingo de ouro 2 and Pingo de ouro 3) had germination percentages less than this value. Marques et al. (2006) evaluated the physiological quality of common bean seeds, with a mean of $64 \%$ in the Pérola cultivar produced in Minas Gerais and $62 \%$ in the Talismã cultivar, produced in the State of Goiás, evaluating the germination of six cultivars of cowpea from the municipalities of Ceará, found germination percentage between $69 \%$ and $88 \%$.

Marques et al. (2006) determined that the germination of six cultivars of cowpea from the municipalities of Ceará werr between $69 \%$ and $88 \%$, compared to $64 \%$ for common bean seeds from a Pérola cultivar produced in Minas Gerais and $62 \%$ for a Talismã cultivar produced in the State of Goiás,

These differences in germination are probably due to the different seed storage systems used by the farmers after harvest until planting. The farmers may use anything from PER bottles to zinc silos for seed storage, and, therefore, they may not provide an ideal environment for seed storage, resulting in decreased seed germination. Without the ideal storage environment, the seed may be exposed to high humidity and determinal temperatures, which when combined with the type of packaging used (generally permeable or semipermeable) has a great influence seed conservation and reduced germination (Antonello et al., 2009). Differences in physiological quality between varieties and seed lots can be attributed not only to the genotype but also to the effects of environmental conditions prevailing during the maturation and harvesting phase (Aguero et al., 1997).

According to Silva et al. (2012), factors such as environmental conditions field seed development, harvest, drying, processing, and storage affect the seed quality. Rapid and uniform germination is important in the 
semi-arid conditions, since water resources are limiting, therefore, the use of a vigorous plant material would minimize the abiotic stresses and decrease the exposure time to the pathogens responsible for the initial infection of seedlings. For the seedling length, the greatest results were observed in the Coruja variety $(4.8 \mathrm{~cm})$, followed by the Pingo de Ouro and Baeta $(4.7$ and $4.5 \mathrm{~cm})$, respectively, whereas the shorter length was observed with the Feijão da Bahia $(3.87 \mathrm{~cm})$ seeds. Evaluating the physiological quality in seeds of common bean varieties cultivated in Vitória da Conquista, State of Bahia, Araújo Neto et al. (2014) also observed significant differences in the seedling lengths of the varieties used, where Carioca $L 1$ varieties increased seedling lengths $t(6.4 \mathrm{~cm})$ compared to Rosinha shorter seedling length $(4.96 \mathrm{~cm})$. Vigorous seedlings give rise to productive plants.

The varieties Epace 10, Baeta and Feijão da Bahia had a greater release of electrolytes during seed imbibition, resulting in higher values of electrical conductivity (145.5, 143.2 and $140.8 \mu \mathrm{S} \mathrm{cm}^{-1} \mathrm{~g}^{-1}$, respectively) in relation to the others. While the lowest conductivities were observed in Pingo de Ouro, Sempre Verde and Coruja (65.33, 106.7 and $132.7 \mu \mathrm{S} \mathrm{cm}^{-1} \mathrm{~g}^{-1}$, respectively) showed greater vigor. This is because the lower the electrical conductivity value correlates to greater membrane integrity and consequently increased seed vigor. The electrical conductivity test can detect the first symptoms of seed deterioration, since it is related to the integrity of cell membranes (Albuquerque et al., 2001; Muasya et al., 2002). These results are consistent with Michels et al. (2014), who studied the physiological quality of bean seeds produced in the western Plateau of Santa Catarina, who was able to classify the varieties in two or more classes regarding the release of solutes, observing that the creole varieties formed the class with lower release of solutes.

In the sanitary analysis of the varieties of cowpea, from farmers of Apodi, Rio Grande do Norte, the presence of phytopathogenic fungi and storage were verified. Similar results were observed by Barreto et al. (2006) who evaluated the health of macassar bean seeds from the municipality of Pombal, State of Paraíba. They found the following pathogens: Aspergillus flavus (28.7\%), Aspergillus niger (20\%) and Fusarium spp. (14.6\%), Penicillium spp. (12.6\%), Cladosporium sp. (7.3\%), Chaetomium sp. (4.6\%), Botrytis sp. (3.7\%), Periconia sp. (2.8\%) and Rhizopus (1.8\%). Silva et al. (2016) evaluating the incidence of pathogens in bean seeds from 37 municipalities of Rio Grande do Norte, found in $94 \%$ of the seed samples, Aspergillus spp. (60\%), Bipolaris sp. (8\%), and Beryllium spp. Colletotrichum spp. (5\%), Fusarium spp. (53\%), Macrophomina sp. (60\%), Penicillium sp. (13\%), Pleurophagminum sp. sp. (70\%), bacteria of the genera Rhizobium sp. $(100 \%)$ and Pantoea sp. (3\%), the pest Callosobruchus maculatus.

The literature has shown that storage fungi, especially Aspergillus and Penicillium sp. (Singh et al., 2007; Biemond et al., 2013) cause most of the cowpea seed deterioration during storage. In the present study it was observed that there were differences between the varieties regarding the incidence of Aspergilus sp., where Epace 10, Baeta and Feijão da Bahia obtained the greatest incidence of this pathogen with 24, 21.75 and 20\%, respectively (Figure 1A). In addition, the Coruja and Pingo de Ouro varieties had a low incidence (less than 10\%) of the pathogen. The presence of Aspergilus sp. may cause reduction in seed germination, especially in those stored with high water content, when this fungus is present in large quantities. These results differ from those observed by Gomes et al. (2008), in which analyzing the physiological quality and incidence of fungi in cowpea beans produced in the State of Ceará, observed a high incidence of Aspergilus in the Pingo de Ouro variety.

The varieties studied also differed in the incidence of Penicillium sp., where Baeta, Epace 10 and Coruja had higher infestations, $14.5 \%, 14 \%$ and $11.5 \%$, respectively (Figure 1B). Silva et al. (2016) also observed the presence of these pathogens in the cowpea varieties from the municipalities of Rio Grande do Norte. These fungi are highly harmful to seeds, reducing germination and causing embryo death, rotting seeds, mass heating with the acceleration of the respiratory rate and its consequent deterioration, besides promoting the production of mycotoxins such as aflatoxin, which is lethal to man and animals (Carvalho \& Nakagawa, 2012). This fact was observed in our research, since the varieties (Baeta, Epace 10 and Feijão da Bahia) that had a higher incidence of these pathogens (Figures 1A and 1B) also presented low germination (Table 1).

In the present study, the presence of Fusarium sp. was greater in the Epace 10, Sempre Verde and Baeta varieties $(8.5,8.5$ and $8 \%$ incidence), respectively (Figure 1C). This fungus has been reported in some sanitary cowpea surveys (Ikran \& Dawar, 2013; Ito et al., 2013). Some Fusarium genera (Fusarium oxysporum and Fusarium solani) are important pathogens for bean culture, being responsible for diseases such as fusariosis, cervix and root rot, and therefore being highly harmful and can drastically reduce yields (Silva et al., 2014). These pathogens not only possess high pathogenicity but can be transmitted by seeds and have the capacity to survive in the soil, even in the absence of the specific host (Sallis, 2001). Silva et al. (2002) reported finding fusarium species inhibited cowpea germination of seeds from Serra Talhada and Caruaru, PE, and observed fungus growth on the cotyledons and leaves, and root necrosis on the seed that did germinate. 
The Baeta did not present an incidence of Cladosporium sp., with a percentage of less than $1.5 \%$ of incidence observed for Coruja, Sempre Verde and Pingo de Ouro. The varieties Epace 10 and Feijão da Bahia had a higher infectious incidence, $10 \%$ and 4\%, respectively (Figure 1D), which corroborate the results obtained by Guimarães and Carvalho (2014), who observed Cladosporium sp. in common bean seeds cv. 'Pérola'. Pérola had spots or greenish growths on the seed surfaces, mainly in the zone corresponding to the embryo, more precisely in the seed thread, and $59.5 \%$ of the seeds were infected.

The genus Rhizopus sp. has little economic importance in respect to seeds, however, it may hinder the detection of other pathogens, because its rapid growth may cover the seeds (Torres \& Bringel, 2005). In the our research, the presence of this fungus was detected in the Baeta (10\%), Coruja (2.5\%), Sempre Verde and Pingo de Ouro $(0.5 \%)$ varieties. Epace 10 and Feijão da Bahia had no incidence of this pathogen (Figure 1E). These results differ from those observed by Silva et al. (2008) in which the genus Rhizopus sp. was also detected in all cultivars, with a higher incidence for the cultivars Sempre Verde and Pingo de Ouro (5\%). Barreto et al. (2016) evaluating the incidence of pathogens in (Gossypium hirsutum L.) treated with agave (Agave angustifolia) strata also identified this fungus.

The pathogens Botrytis sp. and Chaetomium sp. were found in the seeds, but with a low percentage of contamination (less than 3\%). The owl variety had a 1.5\% incidence of Botrytis sp. (Figure 1F). Silva et al. (2008) also observed a low incidence of this pathogen in cowpea beans from Goiás. Other authors have also reported the presence of this fungus, such as Araújo et al. (2013) in seeds of Aroeira (Astronium urundeuva) and Maciel et al. (2012) in Angico Vermeho (Parapiptadenia rigida). Regarding the fungus Chaetomium sp., the highest incidence was recorded in the variety Sempre Verde 5\% (Figure 1G). Similar to the results found by Barreto et al. (2015) that also verified a low incidence (4.6\%) of this fungus in cowpea ( $V$. unguiculata). Kobayasti et al. (2011) found that the seed deterioration the smooth top (Jatropha curcas L.) is related to the presence of Chaetomium sp. The action of this pathogen depends on the physical and physiological conditions of the seeds and the environmental factors that predominate during the storage (Ruiz Filho et al., 2004). 

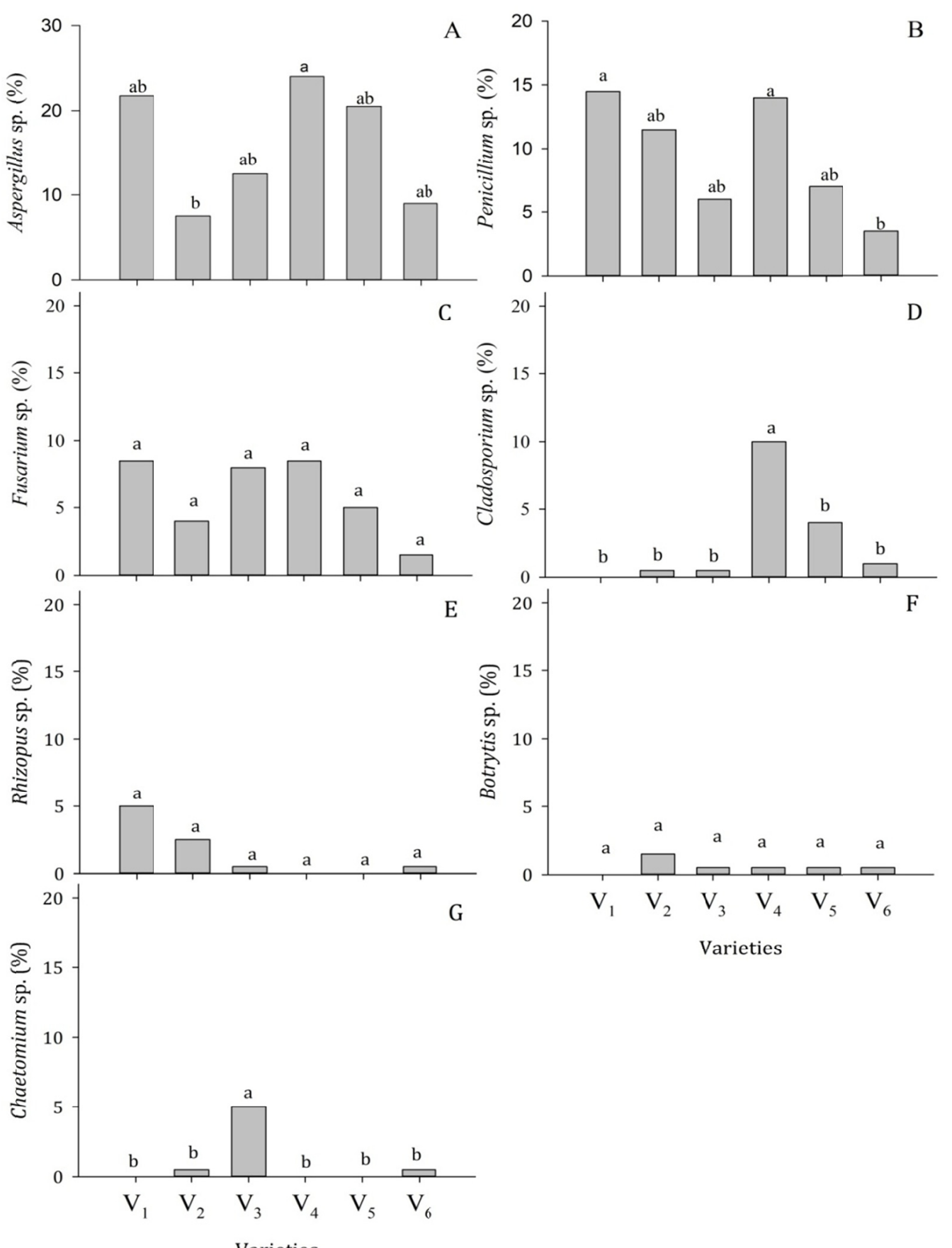

Varieties

Figure 1. Incidence of fungi on seeds of cowpea (Vigna unguiculata L.) produced in the state of Rio Grande do Norte

\section{Conclusions}

The creole cowpea varieties Pingo de Ouro, Sempre Verde and Coruja had germination percentages and vigor above the minimum standards required for commercialization, and recommended for planting. The low germination percentage and vigor of the varieties Feijão da Bahia, Epace 10 and Baeta, may be associated to the presence of Aspergillus sp. and Penicillium sp.

\section{References}

ABRASEM. (Associação Brasileira de Sementes e Mudas). (2017). Retrieved from http://www.abrasem.com.br/ wpcontent/uploads/2012/10/Instru\%C3\%A7\%C3\%A3o-Normativa-n\%C2\%BA-45-de-17-de-Setembro-de- 
2013-Padr\%C3\%B5es-de-Identidade-e-Qualiidade-Prod-e-Comerc-de-Sementes-Grandes-Culturas-Republi ca $\%$ C3\%A7\%C3\%A3o-DOU-20.09.13.pdf

Aguero, J. A. P., Vierira, R. D., \& Bittencourt, S. R. M. (1997). Avaliação da qualidade fisiológica de sementes de variedades de soja. Revista Brasileira de Sementes, 19(2), 255-260. https://doi.org/10.17801/0101-3122/ rbs.v19n2p254-259

Albuquerque, M. C. F., Fabíola, V., Moro, F. V., FagIoli, M., \& Ribeiro, M. C. (2001). Teste de condutividade elétrica e de lixiviação de potássio na avaliação da qualidade fisiológica de sementes de girassol. Revista Brasileira de Sementes, 23(1), 01-08. https://doi.org/10.17801/0101-3122/rbs.v23n1p1-8

Antonello, L. M., Muniz, M. F. B., Brand, S. C., Rodrigues, J., Menezes, N. L., \& Kulczynski, S. M. (2009). Influência do tipo de embalagem na qualidade fisiológica de sementes de milho crioulo. Revista Brasileira de Sementes, 31(4), 75-86. https://doi.org/10.1590/S0101-31222009000400009

Araujo Neto, A. C., Sousa, F. G., Nunes, R. T. C., Moreira, E. S., \& Vasconcelos, R. C. (2014). Qualidade fisiológica em sementes de variedades de feijão comum cultivadas em vitória da conquista-BA. Enciclopédia Biosfera, 10(18), 2583-2014.

Araújo, E. R., Andrade, L. A., Rêgo, E. R., Gonçalves, E. P., \& Araújo, E. (2013). Qualidade fisiológica e sanitária de sementes de aroeira produzidas no estado da Paraíba. Agrotec, 34(1), 9-20. https://doi.org/ 10.25066/agrotec.v34i1.20380

Barreto, A. F., Bonifácio, B. F., Araujo, E., \& Reny, O. (2004). Qualidade fisiológica e a incidência de fungos em sementes de algodoeiro herbáceo tratadas com estratos de agave. Revista de Oleaginosas e Fibrosas, 8(2), 839-849.

Biemond, P. C., Oguntade, O. O., Lava Kuma, P., Stomph, T. J., Termorshuizen, A. J., \& Struik, P. C. (2013). Does the informal seed system threaten cowpea seed health?. Crop Protection, 43, 166-174. https://doi.org/ 10.1016/j.cropro.2012.09.007

Bragantini, C. (2005). Alguns aspectos do armazenamento de sementes e grãos de feijão (p. 28, Documento Técnico, 187). Santo Antônio de Goiás: Embrapa Arroz e Feijão.

Calvet, A. S. F., Pinto, C. M., Lima, R. E. M., Maia-Joca, R. P. M., \& Bezerra, M. A. (2013). Crescimento e acumulação de solutos em feijão-de-corda irrigado com águas de salinidade crescente em diferentes fases de desenvolvimento. Irriga, 18(1), 148-159. https://doi.org/10.15809/irriga.2013v18n1p148

Carvalho, N. M., \& Nakagawa, J. (2012). Sementes: Ciência, tecnologia e produção (p. 590, 5th ed.). Jaboticabal: FUNEP.

Coelho, C. M. M., Mota, M. R., Souza, C. A., \& Miquelluti, D. J. (2010). Potencial fisiológico em sementes de cultivares de feijão crioulo (Phaseolus vulgaris L.). Revista Brasileira de Sementes, 32(3), 97-105. https://doi.org/10.1590/S0101-31222010000300011

CONAB (Compahia Nacional de Abastecimento). (2017). Acompanhamento da safra brasileira de grãos v. 5 (Safra 2017/18, n. 1, Primeiro levantamento). Retrieved from http://www.conab.gov.br/OlalaCMS/ uploads/arquivos/17_10_16_16_34_39_graos_outubro_2017.pdf

Fageria, N. K., Soares Filho, W. S., \& Gheyi, H. R. (2010). Melhoramento genético vegetal e seleção de cultivares tolerantes à salinidade. In H. R. Gheyi, N. da. S. Dias, \& C. F. Lacerda (Eds.), Manejo da salinidade na agricultura: Estudos básicos e aplicados (Cap. 13, pp. 205-216). Fortaleza: INCTSal.

Fernandes, F. B. P., Lacerda, C. F., Andrade, E. M., Neves, A. L. R., \& Sousa, C. H. C. (2015). Efeito de manejos do solo no déficit hídrico, trocas gasosas e rendimento do feijão-de-corda no semiárido. Revista Ciência Agronômica, 46(3), 506-515. https://doi.org/10.5935/1806-6690.20150032

Ferreira, D. F. (2014). Sisvar: A guide for its bootstrap procedures in multiple comparisons. Ciência $e$ Agrotecnolgia, 38(2), 109-112. https://doi.org/10.1590/S1413-70542014000200001

Gomes, D. P., Silva, G. C., Kronka, A. Z., Torres, S. B., \& Souza, J. R. (2008). Qualidade fisiológica e incidência de fungos em sementes de feijão caupi produzidas do Estado do Ceará. Caatinga, 21(2), 165-171.

Guimaraes, G. R., \& Carvalho, D. D. C. (2014). Incidência e caracterização morfológica de Cladosporium herbarum em feijão comum cv. 'Pérola'. Revista Brasileira de Biociencias, 12(3), 137-140.

Henning, A. A. (2005). Patologia e tratamento de sementes: Noções gerais (p. 52). Londrina: Embrapa. 
Ikram, N., \& Dawar, S. (2013). Effect of Prosopis juliflora (Sw.) DC. in the control of root rot fungi of cowpea (Vigna unguiculata L. Walp.) and mung bean (Vigna radiata L. Wilczek). Pakistan Journal of Botany, 45(2), 649-654.

Ito, M. F., Costa, A. F., Pires, B. E., Canuto, V. T. B., Oliveira, L. G., \& Souza, M. C. M. (2013). Sanidade de sementes de feijão-caupi. III CONAC Congresso Nacional de Feijão-Caupi, Recife-PE. Retrieved from http://www.conac2012.org/resumos/pdf/134a.pdf

Kobayasti, L., \& Pires, A. P. (2011). Levantamento de fungos em sementes de trigo. Pesquisa Agropecuária Tropical, 41(4), 572-578. https://doi.org/10.5216/pat.v41i4.12388

Maciel, C. G., Muniz, M. F. B., Santos, A. F., \& Lazarotto, M. (2012). Detecção, transmissão e patogenicidade de fungos em sementes de angico-vermelho (Parapiptadenia rigida). Summa phytopathol, 38(4), 323-328. https://doi.org/10.1590/S0100-54052012000400009

MAPA (Ministério da Agricultura, Pecuária e Abastecimento). (2009). Regras para análise de sementes (p. 399). Brasília: MAPA/ACS.

Marcos Filho, J. (2015). Fisiologia de sementes de plantas cultivadas (p. 495). Piracicaba: FEALQ.

Marques, R. O., Alves, V. M., \& Lima, M. L. P. (2006). Avaliação sanitária e fisiológica de feijão oriundos de Unaí-MG, Paracatu-MG e Cristalina-GO. Summa Phytopathologica, 32, 44.

Michels, A. F., Souza, C. A., Coelho, C. M. M., \& Zilio, M. (2014). Qualidade fisiológica de sementes de feijão crioulo produzidas no oeste e planalto catarinense. Revista Ciência Agronômica, 45(3), 620-632. https://doi.org/10.1590/S1806-66902014000300025

Moraes, S. A. (2006). Amendoim: Principais doenças, manejo integrado e recomendações de controle. Retrieved from http://www.infobibos.com/Artigos/2006_2/Amendoim/index.htm

Muasya, R. M., Lommen, W. J. M., \& Struik, P. C. (2002). Differences in development of common bean (Phaseolus vulgaris L.) crops and pod fractions within a crop. II Seed viability and vigour. Field Crops Research, 75(1), 79-89, https://doi.org/10.1016/S0378-4290(02)00014-X

Rodrigues, A. A. C., \& Menezes, M. (2002). Detecção de fungos endofíticos em sementes de caupi provenientes de Serra Talhada e de Caruaru, Estado de Pernambuco. Fitopatologia Brasileira, 27(5), 532-537. https://doi.org/10.1590/S0100-41582002000500016

Ruiz Filho, R. R., Santos, A. F., Medeiros, A. C. S., \& Jaccoud Filho, D. S. (2004). Fungos associados às sementes de cedro. Summa Phytopathologica, 30(4), 494-496. Retrieved from http://www.alice.cnptia. embrapa.br/alice/handle/doc/428055

Sallis, M. G. V., Maia, M. S., \& Lucca-Filho, O. A. (2001). Fungos associados às sementes de feijão-miúdo (Vigna unguiculata (L.) Walp.) produzidas no município de São José do Norte, RS. Revista Brasileira de Sementes, 23(1), 36-39, https://doi.org/10.17801/0101-3122/rbs.v23n1p36-39

Santos, A. F., Parisi, J. J. D., \& Menten, J. O. M. (2011). Patologia de sementes florestais (p. 236). Colombo: Embrapa Florestas.

Silva, A. L., Almeida, F. A. C., Gomes, J. P., Alves, N. M. C., \& Araújo, D. R. (2012). Qualidade fisiológica e controle de sementes de milho tratadas com Piper nigrum. Revista Brasileira de Produtos Agroindustriais, 14(2), 131-142. https://doi.org/10.15871/1517-8595/rbpa.v14n2p131-142

Silva, F. H. A., Nascimento, S. R. C., Torres, S. B., Oliveira, J. R., Alves, T. R. C., \& Negreiros, A. M. P. (2016). Qualidade sanitária de sementes salvas de feijão-caupi utilizadas pelos agricultores do Rio Grande Norte. Revista de Ciências Agrárias, 59(1), 60-65. https://doi.org/10.4322/rca.2001

Silva, G. C., Gomes, D. F., Kronka, A. Z., \& Moraes. M. H. (2008). Qualidade fisiológica e sanitária de sementes de feijoeiro (Phaseolus vulgaris L.) provenientes do estado de Goiás. Semina: Ciências Agrárias, 29(1), 29-34. Retrieved from http://hdl.handle.net/11449/70277

Silva, G. C., Santos, C. C., \& Gomes, D. P. (2014). Incidência de fungos e germinação de sementes de feijão-caupi (Vigna unguiculata L. (Walp) tratadas com óleo de nim (Azadirachta indica A. Juss). Revista Brasileira Plantas Medicinais, 16(4), 850-855. https://doi.org/10.1590/1983-084X/11_088

Silva, J. A. (2007). Aplicação inicial de $P_{2} O_{5}$ no solo, avaliação em três cultivos sucessivos no feijão caupi (p. 73, Dissertação apresentada ao Programa de Pós-Graduação em Agronomia da Universidade Federal da Paraíba). 
Singh, N. D., Sharma, A. K., Dwivedi, P., Patil, R. D., \& Kumar, M. (2007). Citrinin and endosulfan induced teratogenic effects in Wistar rats: Pathomorphological study. Journal of Applied Toxicology, 27(2), 143-151. https://doi.org/10.1002/jat.1242

Souza, L. M. S., Silva, J. B., \& Gomes, N. S. B. (2013). sanitary quality and germination of copaiba seeds. Bioscience Journal, 29(1), 1524-1531.

Talamini, V., Lima, N. S., Menezes, M. S., Silva, A. M. S., Souza, R. C., \& Silva, L. M. (2010). Qualidade fisiológica e sanitária de sementes de feijão (Phaseolus vulgaris L.) produzidas por agricultores familiares em Sergipe (p. 22, Boletim de Pesquisa e Desenvolvimento 62). Embrapa Tabuleiros Costeiros. Retrieved from http://www.infoteca.cnptia.embrapa.br/infoteca/handle/doc/1014419.pdf

Teófilo, E. M., Dutra A. S., \& Dias, F. T. C. (2006). Avaliação da qualidade fisiológica de sementes de feijão-caupi produzidas em dois municípios cearenses (Documentos 121). Congresso Nacional de Feijão Caupi, Tecnologia Para o Agronegócio, Teresina-PI. Anais... Rio Poty Hotel.

Torres, S. B., \& Bringel, J. M. M. (2005). Avaliação da qualidade sanitária e fisiológica de sementes de feijãomacassar. Revista Caatinga, 18(2), 88-92.

Tropaldi, L., Camargo, J. A., Smarsi, R. C., Kulczynski, S. M., Mendonça, C. G., \& Barbosa, M. M. M. (2010). Qualidade fisiológica e sanitária de sementes de mamona submetidas a diferentes tratamentos químicos. Pesquisa Agropecuária Tropical, 40(1), 89-95. https://doi.org/10.5216/pat.v40i1.5586

Tsutsumi, C. Y., Piano, J. T., \& Bullegon, L. (2015). Melhoramento genético do feijoeiro: Avanços, perspectivas e novos estudos, no âmbito nacional. Nativa, Sinop, 3(3), 217-223. https://doi.org/10.14583/2318-7670. v03n03a12

Vieira, R. D., \& Carvalho, N. M. (1994). Testes de vigor em sementes (p. 164). Jaboticabal: FUNEP.

\section{Copyrights}

Copyright for this article is retained by the author(s), with first publication rights granted to the journal.

This is an open-access article distributed under the terms and conditions of the Creative Commons Attribution license (http://creativecommons.org/licenses/by/4.0/). 